\title{
Regulation of Human Erythrocyte AMP Deaminase by ATP and 2,3-Bisphosphoglycerate
}

\author{
Ryuzo Sasaki, Koji IkURa, Soichiro Katsura \\ and Hideo CHIBA \\ Department of Food Science and Technology, Faculty of Agriculture, \\ Kyoto University, Kyoto 606, Japan \\ Received April 20, 1976
}

\begin{abstract}
AMP deaminase (EC 3.5.4.6) is a key enzyme in the adenine nucleotide metabolism of human erythrocytes. ATP activates the enzyme, while 2,3-bisphosphoglycerate inhibits it. Complexes of magnesium and these organic phosphate compounds are not effectors of AMP deaminase. The AMP deaminase activity in the physiological range of AMP was calculated from AMP-saturation curves which were drawn by measuring the activity under simulated intracellular conditions. Since human erythrocytes have a high level of AMP deaminase, the enzyme activity must be repressed to a low level, which accounts for the half-life of adenine nucleotides in the erythrocyte. Although it is evident from the experimental results that 2,3-bisphosphoglycerate plays an important role in the repression of the activity of this enzyme, the in vivo rate of turnover of adenine nucleotides can not be explained by the inhibitory effect of 2,3-bisphosphoglycerate alone.
\end{abstract}

It is known that adenine nucleotides are the principle nucleotides in mature human erythrocytes and are important in the normal metabolism and functioning of the cells. ${ }^{1 \sim 31}$ In contrast to the metabolic stability of hemoglobin, ${ }^{4 \prime}$ adenine nucleotides in mammalian erythrocytes are in a dynamic state. ${ }^{5,6)}$ Mager et al. have demonstrated that the biological half-life of the adenine moiety of nucleotides in circulating human erythrocytes ranges from eight to nine days. ")

Since mature human erythrocytes can neither synthesize the purine portion of adenine nucleotides from purine ring precursors nor convert IMP to AMP, ${ }^{8,9}$ the phosphorylation of adenosine which is supplied from plasma seems to be important in these cells in the production of adenine nucleotides. ${ }^{103}$ As for their catabolic pathway, AMP deaminase (EC 3.5.4.6) is present in human erythrocytes at a high level. ${ }^{11,12)}$ Since the operation of this enzyme in erythrocytes results in the irreversible loss of the adenine moiety, its regulation may be crucial in the biological

* Abbreviation: 2,3-P $\mathrm{P}_{2}$-glycerate, 2,3-bisphosphoD-glycerate. half-life of adenine nucleotides. Judging from the level of AMP deaminase activity and the half-life of adenine nucleotides, AMP deaminase must be strongly repressed in erythrocytes. AMP deaminase from human erythrocytes is an allosteric enzyme. ${ }^{13 \sim 15}$ ) ATP activates the enzyme, normalizing the velocity-substrate concentration curve to the MichaelisMenten type, whereas 2,3- $\mathrm{P}_{2}$-glycerate* inhibits the enzyme, affecting the position and shape of the curve. Although a physiological significance for this inhibition by $2,3-\mathbf{P}_{2^{-}}$ glycerate has been postulated because of its high level in erythrocytes, ${ }^{13,14}$ it is still unclear whether the 2,3-P $\mathbf{P}_{2}$-glycerate inhibition alone is responsible for the repression of AMP deaminase or if there are additional regulatory factors to the enzyme activity in vivo.

In an attempt to assess the role of $2,3-\mathrm{P}_{2}$ glycerate in the regulation of AMP deaminase, kinetic studies of the enzyme from human erythrocytes have been carried out under simulated intracellular conditions.

\section{MATERIALS AND METHODS}

Chemicals. ATP (disodium salt) and AMP (mono- 
sodium salt) were purchased from the Sigma Chemical Company. Concentrations of adenine nucleotides were determined from their absorption at $259 \mathrm{~nm}$ $\left(E_{268 n \mathrm{~mm}}=15,400 \mathrm{M}^{-1} \times \mathrm{cm}^{-1}\right.$ for ATP and AMP). The cyclohexylammonium salt of 2,3-P $\mathbf{P}_{2}$-glycerate was purchased from Boehringer Mannheim $\mathrm{GmbH}$, and the cyclohexylammonium ion was removed with Amberite IR-120. Phosphoenolpyruvate and NADH were purchased from the Sigma Chemical Company, and solutions of these compounds were prepared on the day of the experiments.

Enzymes. A mixed suspension of crystalline pyruvate kinase (EC 2.7.1.40) and lactate dehydrogenase (EC 1.1.1.27) was purchased from Boehringer Mannheim $\mathrm{GmbH}$.

Assay for AMP deaminase. The activity of AMP deaminase was assayed by measuring the amount of ammonia released from AMP. In the standard assay conditions, the reaction mixture contained 1 mM AMP, $130 \mathrm{~mm} \mathrm{KCl}, 20 \mathrm{~mm} \mathrm{NaCl}$, and $10 \mathrm{~mm}$ Tris- $\mathrm{HCl}$ buffer $\mathrm{pH} 7.2$ (at $37^{\circ} \mathrm{C}$ ), in a total volume of $1.0 \mathrm{ml}$. The reaction was carried out at $37^{\circ} \mathrm{C}$. After the reaction was terminated by the addition of $0.25 \mathrm{ml}$ of $12.5 \%$ trichloroacetic acid, the amount of ammonia was measured by the method of Moore and Stein. ${ }^{16)}$ When precipitable proteins were noted, the sample solution was centrifuged. A portion (usually $1.0 \mathrm{ml}$ ) of the supernatant was used for measurement of ammonia.

Assay for adenylate kinase. The activity of adenylate kinase (EC 2.7.4.3) was assayed by measuring the amount of ADP produced from ATP and AMP. The measurement of ADP was carried out by adding the coupled assay system ${ }^{172}$ to the assay mixture for adenylate kinase. Assays were done at $37^{\circ} \mathrm{C}$ in a total volume of $2.0 \mathrm{ml}$. The reaction mixture contained $1 \mathrm{~mm}$ ATP, $1 \mathrm{~mm}$ AMP, $1 \mathrm{~mm} \mathrm{MgCl}_{2}, 1 \mathrm{~mm}$ phosphoenolpyruvate, $0.1 \mathrm{~mm} \mathrm{NADH}, 0.2 \mathrm{~mm}$ dithiothreitol, $130 \mathrm{mM} \mathrm{KCl}, 20 \mathrm{~mm} \mathrm{NaCl}$, and 3 units of pyruvate kinase and lactate dehydrogenase. The reaction was initiated by the addition of the adenylate kinase preparation, and the disappearance of NADH was followed spectrophotometrically with a Hitachi doublebeam spectrophotometer model 124 equipped with a recorder and a constant-temperature cell compartment.

The activities in all cases were measured under conditions in which initial velocities were determined. One unit of AMP deaminase and adenylate kinase activity is defined as the amount of enzyme which catalyzes the appearance of $1 \mu$ mole of the product (ammonia for AMP deaminase and ADP for adenylate kinase) per min in the assay conditions described above.

Hemolysate. Blood with acid-citrate-dextrose as anticoagulant was obtained from the blood bank.
To remove the serum, the whole blood was centrifuged at $4500 \times g$ for $5 \mathrm{~min}$. The red cells were washed three times with $0.9 \% \mathrm{NaCl}$ solution. The red cells were hemolysed by adding four volumes of $10 \mathrm{mM}$ Tris- $\mathrm{HCl}$ buffer $\mathrm{pH} 7.5$ containing $0.5 \mathrm{~mm}$ dithiothreitol (buffer A). The hemolysate was centrifuged at $30,000 \times g$ for $30 \mathrm{~min}$ to remove the cell membrane. The supernatant was extensively dialysed against buffer $\mathbf{A}$. These procedures were done at $0 \sim 5^{\circ} \mathrm{C}$.

\section{RESULTS}

\section{Preparation of AMP deaminase free of adenylate kinase}

Purification of AMP deaminase from human erythrocytes by using ammonium sulfate fractionation, DEAE-sephadex chromatography, and phosphocellulose chromatography, yielded enzyme insensitive to $2,3-\mathrm{P}_{2}$-glycerate inhibition. Desensitization of the allosteric properties of this enzyme has also been reported..$^{15}$ ) Since human erythrocytes have adenylate kinase at an extremely high level, ${ }^{3)}$ however, an AMP deaminase preparation free of adenylate kinase was needed for experiments to be carried out in the presence of ATP,

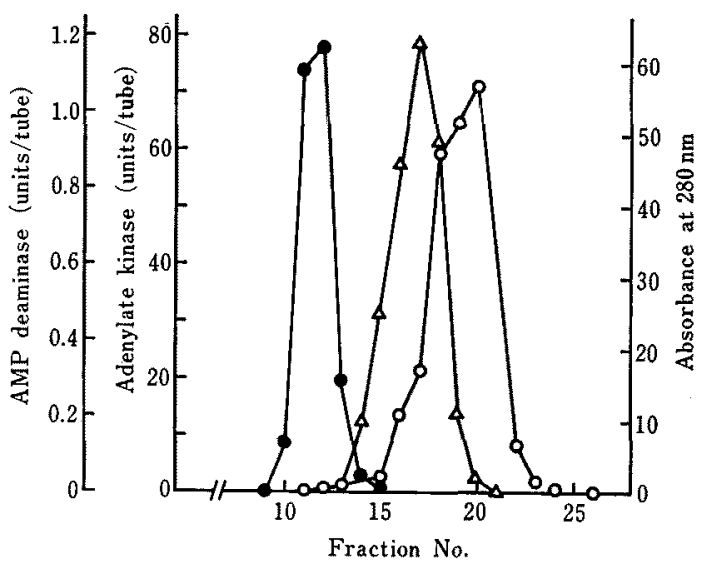

FIG. 1. Separation of AMP Deaminase and Adenylate Kinase by Sephadex G-75.

$\triangle-\triangle$, absorbance at $280 \mathrm{~nm}$; $-\bullet$, AMP deaminase; $\mathrm{O}-\mathrm{O}$, adenylate kinase. Both enzyme activities were measured under the standard assay conditions described in the text and were expressed as units per fraction. Ten $\mathrm{ml}$ of the hemolysate was added to a column $(2.0 \times 56 \mathrm{~cm})$ containing Sephadex G-75 previously equilibrated with buffer $A$ and the column was developed with the same buffer. Flow rate was $23 \mathrm{ml}$ per hr. One fraction was $5 \mathrm{ml}$. Temperature was $5^{\circ} \mathrm{C}$. 
AMP and magnesium. The molecular weight of adenylate kinase is about $23,000{ }^{18}$ ) while that of AMP deaminase is greater than 100,000 (unpublished result). The difference in molecular weight between these two enzymes made it possible to obtain an adenylate kinase-free preparation. Separation of the two enzymes was achieved by performing Sephadex G-75 chromatography of the hemolysate as shown in Fig. 1. Fractions 11 and 12 were used for the following experiments. The adenylate kinase activity in these fractions was so small that no detectable decrease of ATP was observed when ATP, AMP, and magnesium were present in the AMP deaminase assay mixture. Furthermore, these AMP deaminase preparations showed the same sensitivities with respect to ATP activation and 2,3- $\mathrm{P}_{2}$-glycerate inhibition as the dialysed hemolysate did.

\section{Effect of 2,3-P $P_{2}$-glycerate and $M g \cdot 2,3-P_{2}-g l y-$ cerate on AMP deaminase}

2,3- $\mathrm{P}_{2}$-Glycerate and ATP in human erythrocytes bind not only with hemoglobin but also with magnesium. It is not known if the complexes of these organic phosphate compounds with magnesium act as allosteric effectors on AMP deaminase as well as the free compounds. Figure $2 \mathrm{~A}$ shows the re- sponse of AMP deaminase activity to $2,3-\mathrm{P}_{2^{-}}$glycerate in the presence and the absence of magnesium. Addition of magnesium reduces the extent of inhibition by $2,3-\mathrm{P}_{2}$-glycerate, indicating that the 2,3- $\mathrm{P}_{2}$-glycerate $\cdot$ magnesium complex has no effect on this enzyme's activity. Magnesium at the concentration tested has no effect on the enzyme activity in the absence of 2,3-P $\mathrm{P}_{2}$-glycerate. Concentrations of free 2,3- $\mathrm{P}_{2}$-glycerate were calculated by using an association constant of $0.6 \mathrm{mM}^{-1}$ for $2,3-\mathrm{P}_{2^{-}}$ glycerate and magnesium. ${ }^{20}$ When the Fig. $2 \mathrm{~A}$ values for the enzyme activity were replotted against concentrations of free 2,3- $\mathrm{P}_{2-}$ glycerate, all data could be expressed by a single 2,3- $\mathbf{P}_{2}$-glycerate response curve (Fig. 2B). It is evident from these results that free 2,3- $\mathbf{P}_{2}$-glycerate, but not its magnesium complex, inhibits AMP deaminase.

\section{Effect of ATP and $M g \cdot A T P$ on AMP deaminase}

The same kind of experiments as in the case of 2,3- $\mathrm{P}_{2}$-glycerate were carried out in order to determine whether the $\mathrm{Mg} \cdot \mathrm{ATP}$ complex activated AMP deaminase activity as did free ATP. Figure 3A shows the stimulatory effect of ATP on the enzyme inhibited by 2,3- $\mathrm{P}_{2}$-glycerate. The stimulatory effect was reduced by adding magnesium. Since the
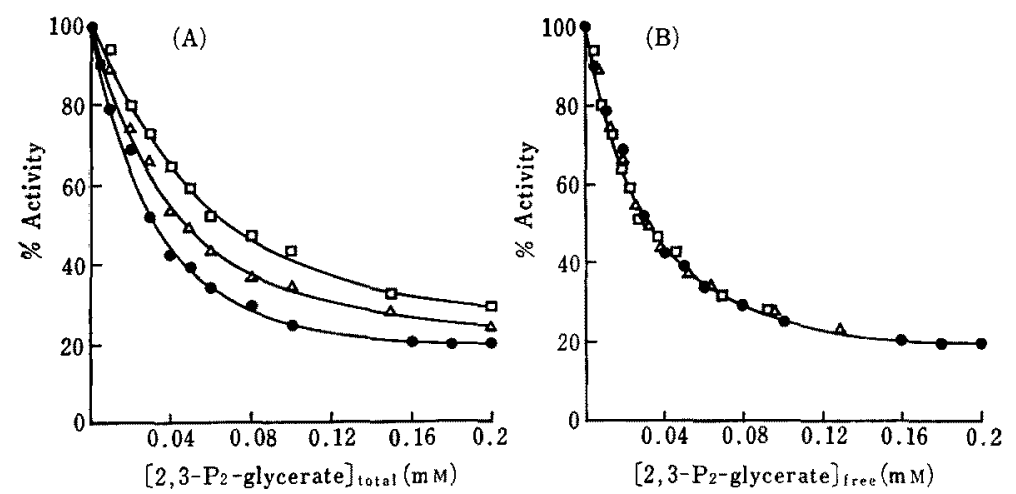

FIG. 2. Inhibition of AMP Deaminase by 2,3-P $\mathrm{P}_{2}$-Glycerate and Effect of $\mathrm{MgCl}_{2}$ on the Inhibition.

The enzyme activity was measured under standard assay conditions except that various amounts of 2,3- $\mathrm{P}_{2}$-glycerate and $\mathrm{MgCl}_{2}$ were added. - - no $\mathrm{MgCl}_{2} ; \triangle-\triangle, 1 \mathrm{mM} \mathrm{MgCl} ; \square-\square, 2 \mathrm{mM}$ $\mathrm{MgCl}_{2}$. In (A), the activity was plotted with total $2,3-\mathrm{P}_{2}$-glycerate concentration as the abscissa. In $(B)$, the same results were replotted with free $2,3-\mathrm{P}_{2}$-glycerate concentration calculated from an association constant $\left(0.6 \mathrm{mM}^{-1}\right)$ for $2,3-\mathrm{P}_{2}$-glycerate and magnesium. ${ }^{1 \theta)}$ The enzyme activity was determined by using $8.5 \times 10^{-3}$ unit of enzyme, and $100 \%$ activity was defined as the activity observed in the absence of $2,3-\mathrm{P}_{2}$-glycerate. 

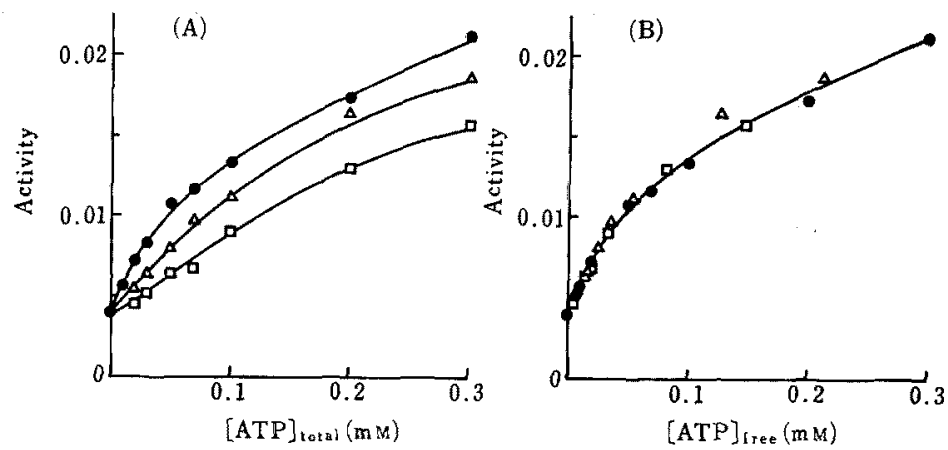

Fig. 3. Activation of AMP Deaminase by ATP and Effect of $\mathrm{MgCl}_{2}$ on the Activiation.

The enzyme activity was measured under standard assay conditions except that $0.2 \mathrm{Hr} \cdot \mathrm{M} 2,3-\mathrm{P}_{\mathrm{z}^{-}}$ glycerate and various amounts of ATP and $\mathrm{MgCl}_{2}$ were added. $-\longrightarrow$, no $\mathrm{MgCl}_{2} ; \Delta-\Delta 0.125 \mathrm{mM}$ $\mathrm{MgCl}_{2} ; \square-\square 0.250 \mathrm{mM} \mathrm{MgCl}$. In (A), the activity was plotted with total ATP concentration as absciassa. In (B), the same results were replotted with the free ATP concentration calculated from an association constant $\left(12 \mathrm{mM}^{-1}\right)$ for ATP and magnesium and that $\left(0.6 \mathrm{~mm}^{-1}\right)$ for $2,3-\mathrm{P}_{2}$-glycerate and magnesium. ${ }^{19)}$ The enzyme activity was determined by using $1.7 \times 10^{-2}$ unit of enzyme, and was expressed as $\mu$ moles of $\mathrm{NH}_{3}$ produced per min.

association constant $\left(12 \mathrm{~mm}^{-1}\right)$ for magnesium and ATP is much greater than that for magnesium and 2,3- $\mathrm{P}_{2}$-glycerate, ${ }^{197}$ the reduction of the ATP activation was observed at relatively low concentrations of magnesium. Therefore, under the experimental conditions, the decrease in the free $2,3-\mathrm{P}_{2}$-glycerate concentration through formation of $\mathrm{Mg} \cdot 2,3-\mathrm{P}_{2}$ glycerate and the subsequent relief of the enzyme from $2,3-\mathrm{P}_{2}$-glycerate inhibition could be ignored. As shown in Fig. 3B, when the data in Fig. 3A were plotted with the free ATP concentration as the abscissa, a single curve was obtained to which all the data fitted. It was concluded that free ATP, but not its $\mathrm{Mg}$ complex, activated AMP deaminase.

\section{AMP deaminase activity under simulated intra- cellular conditions}

As described above, free 2,3- $\mathrm{P}_{2}$-glycerate and ATP act as allosteric effectors of AMP deaminase. Gerber et al. ${ }^{20}$ have reported the intracellular distribution of ATP, 2,3- $\mathrm{P}_{2^{-}}$ glycerate, and magnesium in oxygenated and deoxygenated human erythrocytes. One can estimate AMP deaminase activity under intracellular conditions regarding ionic strength, $\mathrm{pH}$, temperature, AMP, ATP, and 2,3- $\mathrm{P}_{2}$ glycerate. Figure 4 shows substrate-satura-

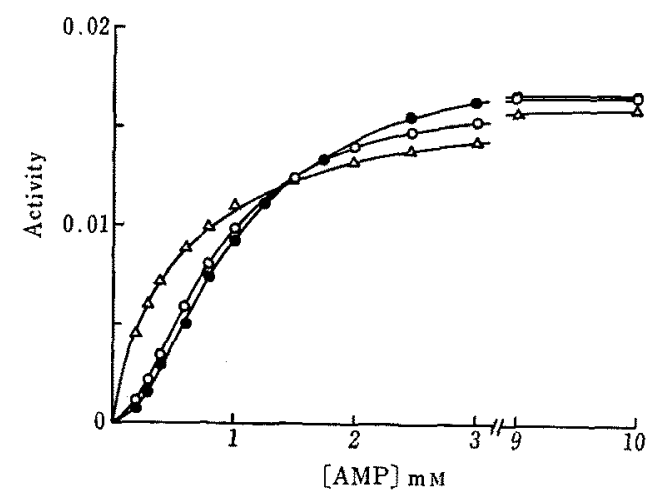

FIG. 4. Substrate-saturation Curve of AMP Deaminase under Simulated Intracellular Conditions.

The activity was measured under standard assay conditions except that various amounts of the effectors were added. The concentrations of effectors were $\triangle \rightarrow \triangle, \quad[\mathrm{ATP}]=0.18 \mathrm{~mm}, \quad\left[2,3-\mathrm{P}_{2}\right.$-glycerate $]=$ $0 \mathrm{mM} ;-\left[\right.$ - $,[A T P]=0.18 \mathrm{~mm},\left[2,3-\mathrm{P}_{\mathrm{z}}\right.$-glycerate $]=$ $3.2 \mathrm{~mm} ; \mathrm{O}-\mathrm{O},[\mathrm{ATP}]=0.11 \mathrm{~mm},\left[2,3-\mathrm{P}_{\mathrm{s}}\right.$-glycerate $]=$ $1.2 \mathrm{~mm}$. Concentrations of effectors simulated those of oxygenated - and the deoxygenated $\mathrm{O}-\mathrm{O}$, erythrocytes. $^{20}$ In (B), the rusults of (A) were plotted according to the Hill equation. The activity was determined by using $8.3 \times 10^{-3}$ unit of enzyme and was expressed as $\mu$ moles of $\mathrm{NH}_{3}$ produced per min.

tion curves obtained by varying the AMP concentration, keeping effector concentrations constant. In the presence of ATP alone $(0.18 \mathrm{~mm})$, a hyperbolic substrate-saturation curve was observed. When ATP and 2,3-P- 
Table I. Kinetic Parameters

The kinetic parameters in the Hill equation $\left(v=\mathrm{V}[\mathrm{AMP}]^{\mathrm{n}} / K+[\mathrm{AMP}]^{\mathrm{n}}\right)$ were calculated by replotting the data in Fig. 4 according to Monod et al. ${ }^{21}$

\begin{tabular}{cccc} 
& $\begin{array}{c}{[\mathrm{ATP}]=0.18 \mathrm{mM}} \\
{\left[2,3 \mathrm{DPG}{ }^{a}\right]=0 \mathrm{mM}}\end{array}$ & $\begin{array}{c}{[\mathrm{ATP}]=0.18 \mathrm{mM}} \\
{[2,3 \mathrm{DPG}]=3.2 \mathrm{mM}}\end{array}$ & $\begin{array}{c}{[\mathrm{ATP}]=0.11 \mathrm{mM}} \\
{[2,3 \mathrm{DPG}]=1.2 \mathrm{mM}}\end{array}$ \\
\hline$n$ & 1.00 & 2.10 & 1.85 \\
$K$ & 0.53 & 0.81 & 0.71 \\
\hline
\end{tabular}

a) 2,3-Bisphosphoglycerate (2,3- $\mathrm{P}_{2}$-glycerate).

Table II. AMP Deaminase Activity in Human Erythrocytes

The enzyme activity $(v)$ was calculated by using the kinetic parameters in Table I and was expressed as $\mu$ moles of AMP converted in one $\mathrm{ml}$ of human erythrocytes per min. Conditions ([ATP] $=0.18 \mathrm{~mm}$ and $\left[2,3-\mathrm{P}_{2}\right.$-glycerate $]=3.2 \mathrm{mM}$ or $[\mathrm{ATP}]=0.11 \mathrm{mM}$ and $\left[2,3-\mathrm{P}_{2}\right.$-glycerate $]=1.2 \mathrm{mM}$ ) correspond to oxygenated or deoxygenated state of human erythrocytes.

\begin{tabular}{cccc}
\hline & \multicolumn{3}{c}{$v \times 10^{3}$} \\
\cline { 2 - 4 }$(\mathrm{AMP}]$ & $\begin{array}{c}{[\mathrm{ATP}]=0.18 \mathrm{mM}} \\
{\left[2,3 \mathrm{DPG}^{a}\right]=0 \mathrm{mM}}\end{array}$ & $\begin{array}{c}{[\mathrm{ATP}]=0.18 \mathrm{mM}} \\
{[2,3 \mathrm{DPG}]=3.2 \mathrm{mM}}\end{array}$ & $\begin{array}{c}{[\mathrm{ATP}]=0.11 \mathrm{mM}} \\
{[2,3 \mathrm{DPG}]=1.2 \mathrm{mM}}\end{array}$ \\
\hline 0.01 & 37.0 & 0.16 & 0.56 \\
0.02 & 72.7 & 0.67 & 2.02 \\
0.03 & 107.1 & 1.56 & 4.28 \\
0.04 & 140.4 & 2.86 & 7.28 \\
0.05 & 172.4 & 4.56 & 10.98 \\
\hline
\end{tabular}

a) 2,3-Bisphosphoglycerate(2,3-P $\mathbf{P}_{2}$-glycerate).

Table III. Half-life of Adenine Nucleotide in Human Erythrocytes

Half-life (half of the total adenine nucleotide/the AMP deaminase activity in Table II) was expressed as the time required to renew half of the adenine nucleotides in human erythrocytes. Conditions ([ATP $]=$ $0.18 \mathrm{mM}$ and $\left[2,3-\mathrm{P}_{2}\right.$-glycerate $]=3.2 \mathrm{mM}$ or $[A T P]=0.11 \mathrm{mM}$ and $\left[2,3-\mathrm{P}_{2}\right.$-glycerate $]=1.2 \mathrm{~mm}$ ) correspond to oxygenated or deoxygenated state of human erythrocytes.

\begin{tabular}{cccc}
\hline & \multicolumn{3}{c}{ Half-life $(\mathrm{hr})$} \\
\cline { 2 - 4 }$(\mathrm{AMP}]$ & {$[\mathrm{mM})$} & {$[\mathrm{ATP}]=0.18 \mathrm{mM}$} & {$[\mathrm{ATP}]=0.18 \mathrm{mM}$} \\
{$\left[2,3 \mathrm{DPG}{ }^{0}\right]=0 \mathrm{mM}$} & {$[2,3 \mathrm{DPG}]=3.2 \mathrm{mM}$} & $\begin{array}{c}\text { [ATP] }=0.11 \mathrm{mM} \\
{[2,3 \mathrm{DPG}]=1.2 \mathrm{mM}}\end{array}$ \\
\hline 0.01 & 0.52 & 119.8 & 34.2 \\
0.02 & 0.26 & 28.6 & 9.5 \\
0.03 & 0.18 & 12.3 & 4.5 \\
0.04 & 0.14 & 6.7 & 2.6 \\
0.05 & 0.11 & 4.2 & 1.7 \\
\hline
\end{tabular}

a) 2,3-Bisphosphoglycerate(2,3-P $\mathbf{P}_{2}$-glycerate).

glycerate were added so as to simulate conditions in oxygenated or deoxygenated human erythrocytes, substrate-saturation curves were sigmoidal. By using the modified Hill equations, ${ }^{21)}$ these curves were converted to linear plots (not shown) in order to estimate the kinetic parameters which are given in Table I. In separate experiments, maximal AMP de- aminase activity was determined by using the dialysed hemolysate, and its value was converted to maximal activity in erythrocytes. It was found that one $\mathrm{ml}$ of human erythrocytes could convert at the maximum $2 \mu$ moles of AMP to IMP in one min. Therefore, AMP deaminase activities in the physiological range of AMP could be calculated by using the 
kinetic parameters in Table I. The calculated values are shown in Table II. The adenylate kinase reaction must be close to equilibrium in human erythrocytes, because of the presence of adenylate kinase at an extremely high level. ${ }^{22,23}$ ) Since the conversion of AMP to IMP is the rate-limiting step in the catabolic pathway of adenine nucleotide in human erythrocytes, a renewal rate of the nucleotide must be dependent on AMP deaminase activity. The concentration of the total adenine nucleotide is about $2.3 \mathrm{~mm}$ in human erythrocytes. ${ }^{20)}$ Hence, the half-life of adenine nucleotides can be calculated by using the values in Table II. Half-lives at various concentrations of AMP are expressed in Table III as the time required to renew half of the nucleotide. The values obtained in the physiological range of AMP were much smaller than the half-life ( $8 \sim 9$ days) of adenine nucleotides reported by Mager et $a l^{7}{ }^{7}$ In the presence of ATP alone, however, the times required are much smaller than those obtained in the presence of ATP and 2,3- $\mathrm{P}_{2}$-glycerate. From these results, it appears that $2,3-\mathrm{P}_{2}$-glycerate contributes not totally but only partially in the regulation of AMP deaminase in human erythrocytes.

\section{DISCUSSION}

Although Lian and Harkness suggested that 2,3- $\mathrm{P}_{2}$-glycerate plays a minor role in the regulation of AMP deaminase in human erythrocytes, ${ }^{15}$ an enzyme preparation partially desensitized to the 2,3- $\mathrm{P}_{2}$-glycerate inhibition was used in the experiments. Furthermore, variations of concentrations of the effectors (ATP and 2,3- $\mathrm{P}_{2}$-glycerate) in erythrocytes through formation of complexes between these effectors and magnesium or hemoglobin had not been taken into consideration.

There are clinical reports which suggest that 2,3- $\mathrm{P}_{2}$-glycerate may not be important in the regulation of AMP deaminase. ${ }^{24,25 \text {, }}$ These papers described bisphosphoglyceromutase deficiencies in which $2,3-\mathrm{P}_{2}$-glycerate concentrations were decreased, while adenine nucleotides were at a normal level. This observation, however, does not seem to be direct evidence for a minor role of 2,3- $\mathrm{P}_{2}$ glycerate in adenine nucleotide metabolism. A decrease in the 2,3- $\mathbf{P}_{2}$-glycerate concentration would elevate the ratios of $\mathrm{Mg} \cdot \mathrm{ATP}$ and hemoglobin-ATP complexes to free ATP, as compared with erythrocytes containing $2,3-\mathrm{P}_{2}$ glycerate at a normal level. Reduction of AMP deaminase activity due to the decrease of free ATP concentrations may result in a normal level of adenine nucleotide in the erythrocytes which are deficient in bisphosphoglyceromutase.

We have estimated AMP deaminase activity under simulated intracellular conditions by using an enzyme preparation showing the same sensitivity to $2,3-\mathrm{P}_{2}$-glycerate inhibition as did the hemolysate. The results indicate that 2,3- $\mathrm{P}_{2}$-glycerate does contribute to delay the metabolic decay of adenine nucleotides by the action of AMP deaminase. However, the effect of ATP on the enzyme inhibited by 2,3- $\mathrm{P}_{2}$-glycerate reduces the inhibitory effect, so as not to be accountable for the half-life of adenine nucleotides in human erythrocytes.

Although there is no clue to additional regulatory factors of AMP deaminase at present, the following comments would be worth consideration. (1) The complex of magnesium and 2,3-P $\mathrm{P}_{2}$-glycerate has no effect on the AMP deaminase, but the effect of the hemoglobin $\cdot 2,3-\mathrm{P}_{2}$-glycerate complex remains to be tested. (2) It has been found that $2,3-\mathrm{P}_{2^{-}}$glycerate metabolism in human erythrocytes is regulated not only by mechanisms observed in many metabolic pathways, ${ }^{26,27)}$ but also by the unique feature that the enzyme responsible for the metabolism is multifunctional. ${ }^{28,29)}$ It has been suggested as an additional regulatory factor that a substantial portion of 2,3-P $\mathrm{P}_{2^{-}}$ glycerate might be synthesized by the membrane system. $^{301}$ A portion of the AMP deaminase of human erythrocytes was found in the membrane fraction. ${ }^{31)}$ It is tempting to attach some significance to compartmentalization of both enzymes in erythrocytes. ' (3) Searching of metabolites which can inhibit the 
AMP deaminase independently or synergistically with $2,3-\mathrm{P}_{2}$-glycerate should be continued.

\section{REFERENCES}

1) C. Bishop, D. M. Rankine and J. H. Talbott, J. Biol. Chem., 234, 1233 (1959).

2) M. Nakao, "Cellular and Molecular Biology of Erythrocytes," ed. by H. Yoshikawa and S. M. Rapoport, University of Tokyo Press, 1974, p. 35.

3) G. Jacobasch, S. Minakami and S. M. Rapoport, "Cellular and Molecular Biology of Erythrocytes," ed. by H. Yoshikawa and S.M. Rapoport, University of Tokyo Press, 1974, p. 55.

4) D. Shemin and D. Rittenberg, J. Biol. Chem., 166, 627 (1946).

5) C. Bishop, ibid, 236, 1778 (1961).

6) B. A. Lowy, B. Ramot and I. M. London, ibid., 235, 2920 (1960).

7) J. Mager, A. Dvilansky, A. Razin, E. Wind and G. Izak, Israel J. Med. Sci, 2, 297 (1966).

8) C. Bishop, J. Biol. Chem., 235, 3228 (1960).

9) B. A. Lowy, M. K. Williams and I. M. London, ibid., 237, 1622 (1962).

10) F. L. Meyskens and H. E. Williams, Biochim. Biophys. Acta, 240, 170 (1971).

11) E. J. Conway and R. Cooke, Nature, 142, 720 (1938).

12) E. J. Conway and R. Cooke, Biochem. J., 33, 479 (1939).

13) A. Askari and J.E. Franklin, Jr., Biochim. Biophys. Acta, 110, 162 (1965).

14) A. Askari and S. N. Rao, ibid., 151, 198 (1968).

15) C. Lian and D. R. Harkness, Biochim. Biophys. Acta, 341, 27 (1974).
16) S. Moore and W.H. Stein, J. Biol. Chem., 211, 907 (1954).

17) T. Bucher and G. Pfleiderer, "Methods in Enzymology," Vol. I, ed. by S. P. Colowick and N. O. Kaplan, Academic Press Inc., New York, N.Y., 1955, p. 435.

18) C. Brownson and N. Spencer, Biochem. J., 130, 797 (1972).

19) H. Berger, G. R. Jänig G. Gerber K. Ruckpaul and S. M. Rapoport, Eur. J. Biochem., 38, 553 (1973).

20) G. Gerber, H. Berger, G. R. Jänig and S. M. Rapoport, ibid., 38, 563 (1973).

21) J. Monod, J. P. Changeux and F. Jacob, J. Mol. Biol., 6, 306 (1963).

22) H. Friedemann and S. M. Rapoport, "Cellular and Molecular Biology of Erythrocytes," ed. by H. Yoshikawa and S. M. Rapoport, University of Tokyo Press, Japan, 1974, p. 181.

23) I. A. Rose, Proc. Natl, Acad. Sci. U.S.A., 61, 1079 (1968).

24) G. Jacobasch, 1. Sylm-Rapoport, H. Roigas and S. Rapoport, Clin. Chim. Acta, 10, 477 (1964).

25) D. Labie, J.-P. Leroux, A. Najman and C. Reyrolle, FEBS Lett., 9, 37 (1970).

26) Z. B. Rose J. Biol. Chem., 243, 4810 (1968).

27) Z. B. Rose and J. Liebowitz, ibid., 245, 3232 (1970).

28) R. Sasaki, K. Ikura, E. Sugimoto and H. Chiba, Eur. J. Biochem., 50, 581 (1975).

29) K. Ikura, R. Sasaki, H. Narita, E. Sugimoto and H. Chiba, ibid., 66, 515 (1976).

30) P. Arese, A. Bosia and G. P. Pescarmona, FEBS Lett., 49, 33 (1974).

31) S. N. Rao, L. Hara and A. Askari, Biochim. Biophy's. Acta 151, 651 (1968). 